\title{
Biodistribution and Feasibility of Non-Viral IGF-I Gene Transfers in Thermally Injured Skin
}

\author{
Marc G. Jeschke, Robert E. Barrow, Hal K. Hawkins, Ziming Tao, \\ J. Regino Perez-Polo, and David N. Herndon
}

Shriners Hospital for Children, and the Departments of Surgery (MGJ, REB, HKH, DNH) and Human Biological
Chemistry and Genetics (ZT, JRP-P), University of Texas Medical Branch, Galveston, Texas

SUMMARY: Gene therapy using cationic liposomes containing cDNA is a relatively new approach with great potential; however, little is known about the mechanisms of dermal gene transfer, its biodistribution, systemic transfection, and cellular uptake. This study identifies mechanisms, transfection rates, and biodistribution of liposomal gene transfers in the skin of thermally injured rats using cDNA gene constructs coding for insulin-like growth factor-I (IGF-I) and Lac Z. Male Sprague-Dawley rats (350 to $375 \mathrm{~g}$ ) were given a $60 \%$ total body surface area full-thickness scald burn that was followed by weekly subcutaneous injections of normal saline (control, $n=10$ ), liposomes plus $0.2 \mu \mathrm{g}$ Lac Z cDNA construct driven by a cytomegalovirus (CMV) promoter (vehicle, $n=10$ ), or liposomes containing $2.2 \mu \mathrm{g}$ cDNA coding for IGF-I plus $0.2 \mu \mathrm{g}$ Lac Z cDNA construct driven by a CMV promoter (IGF-I CDNA, $n=10$ ). Gene transfection was determined by histochemical and luminescent $\beta$-galactosidase assays of blood, skin, liver, spleen, and kidney. Transcription of IGF-I cDNA to IGF-I mRNA was determined in skin cells by Northern blot analyses. Levels of IGF-I protein in blood, skin, liver, spleen, and kidney were measured by radioimmunoassay. The biological activity of the translated IGF-I was evaluated by the mitogenic activity in dermal cells and the rate of re-epithelization. Gene transfection was observed only in skin cells. The expression of IGF-I mRNA increased in skin cells of burned rats receiving liposomes containing the IGF-I cDNA construct compared with liposomes without the construct or normal saline. IGF-I protein levels in the skin of rats receiving the IGF-I cDNA was $176 \pm 4 \mathrm{ng} / \mathrm{ml}$ compared with $105 \pm 6 \mathrm{ng} / \mathrm{ml}$ for liposomes alone or $90 \pm$ $3 \mathrm{ng} / \mathrm{ml}$ for saline $(p<0.05)$. The translated IGF-I protein was found biologically active in the skin by increasing skin cell proliferation and accelerating re-epithelization 33 days after thermal injury $(p<0.05)$. No systemic transfection could be detected. Skin cells transfected with liposomes encapsulating the IGF-I cDNA constructs increased the expression of IGF-I mRNA transcript and the expression of a biologically active IGF-I protein. Liposomes containing the cDNA coding for IGF-I present an effective approach to gene therapy in the skin. (Lab Invest 2000, 80:151-158).

$G$ ene transfer is a unique approach to the treatment of various clinical disorders such as cancer, infection, and some neurological and cardiac diseases (Firedmann, 1997). For successful gene delivery, the selection of an appropriate vector has been shown to be paramount (Felgner, 1997; Firedmann, 1997). Viruses, in particular adenoviruses with their specific transfection capabilities, have been used as gene vectors (Felgner, 1997; Felgner et al, 1995; Firedmann, 1997). Viruses, however, display infectionassociated toxicity, immunologic compromise, and possible mutagenic or carcinogenic effects that make this approach potentially dangerous (Firedmann, 1997). Although naked DNA includes no viral components, naked DNA is not stable in the body and with its relatively large size and electric charge is not likely to penetrate the cells. As a vector for gene therapy, liposomes have become attractive because of their non-viral composition, stability, and ability to interact with the cell membrane (Felgner, 1996). The incorpo-

Received August 25, 1999.

Address reprint requests to: Dr. M. G. Jeschke, Klinik und Poliklinik für Chirurgie, Klinikum der Universität Regensburg, Franz-Joseph-Strauss Allee 11, 93053 Regensburg, Germany. Fax: 941944 6802; E-mail: Mcjeschke@hotmail.com ration of cholesterol and the addition of cationic properties to the standard liposomal structure, together with the use of cytomegalovirus (CMV) promoters in the cDNA constructs, increase the efficacy and transgenic expression equal to those achieved with adenoviral constructs (Felgner, 1996; Wheeler et al, 1996). The flexibility in the design of cationic lipid structures and the variety of methods used in the liposomal preparation broaden their scope for the therapeutic use (Lee et al, 1996; Mahato et al, 1998).

Skin gene therapy is a relatively new approach with great potential because of the accessibility and the possibility to monitor the modified area (Alexander and Akhurst, 1995). Several investigations have proposed that gene transfer in the skin, using non-viral techniques, may be effective. The topical application of DNA for $\beta$-galactosidase rapidly penetrates the skin with the $\beta$-galactosidase gene mainly expressed in the dermis, epidermis, and follicular keratinocytes (Alexander and Akhurst, 1995; Li and Hoffman, 1995a, 1995b; Palmer et al, 1991). Despite the obvious possibilities of applying gene therapy to the skin, little is known of the mechanisms of dermal gene transfer, biodistribution properties, systemic transfection or deposition, cellular uptake, and whether the translated protein is biologically effective. 
The purpose of the present study was to determine the effects of in vivo liposomal gene transfer in the skin, its biodistribution, deposition in organ systems, cellular uptake, and whether the genetically translated protein is biologically active. To investigate these mechanisms, cholesterol-containing cationic liposomes encapsulating the Lac $Z$ gene for $\beta$-galactosidase and the cDNA gene for insulin-like growth factor-I (IGF-I) were subcutaneously injected in the skin of thermally injured rats. The burn wound was chosen because of high cell activity and high proliferation rates, which have been shown necessary for effective dermal gene transfer, and to test the hypothesis that the translated protein has a biological influence in a pathological state (Felgner et al, 1995). The rates of transfection, transcription, and translation in the skin and systemic cells were based on $\beta$-galactosidase and IGF-I expression. The biological efficacy of the translated IGF-I gene was evaluated by the mitogenic activity in dermal cells and the rate of re-epithelization (Herndon et al, 1990; Martin, 1997).

\section{Results}

\section{Transfection}

Transfection of skin cells in thermally injured rats was determined by Bluo-Gal staining. The fine granular blue-green reaction product of the $\beta$-galactosidase reaction was predominantly present in the granulation tissue; the reaction product is composed of spindleshaped myofibroblasts, macrophages, and growing small blood vessels underlying the wound. The cells consistently staining for $\beta$-galactosidase were myofibroblasts, endothelial cells, and macrophages located in the areas of inflammation and included multinucleate giant cells, indicating preferential transfection of cells with higher proliferation rates (Fig. 1, a and b). Although most staining for $\beta$-galactosidase was in the cytoplasm, some reaction products were observed outside the cell boundaries, possibly due to enzymes released by dead cells or the simple diffusion of reaction products. A small amount of reaction product was also detected in the matrix of hair follicles near the injection sites. No $\beta$-galactosidase was detected in saline-treated animals, as depicted in Figure 1, c and d.

Beta-galactosidase protein expression was increased around the wound perimeter in rats receiving liposome-encapsulated Lac Z cDNA plus IGF-I cDNA constructs when compared with saline-treated rats, $p<0.05$ (Table 1). There was no difference among groups for $\beta$-galactosidase concentrations in blood cells, liver, spleen, or kidney. This finding is consistent with the conclusion that systemic cells were not transfected after subcutaneous cDNA injections (Table 2).

\section{Transcription}

In skin biopsies, taken 33 days after burn, Northern blots showed a significant amount of IGF-I mRNA transcript in the skin after transfection with lipoplexes containing the cDNA coding for IGF-I. No IGF-I mRNA could be detected in the skin proximal to transfection sites in the control or vehicle-treated rats (Fig. 2).

\section{Translation}

In all skin biopsies taken 33 days after burn and 5 days after the last injection, animals treated with the IGF-I cDNA constructs had higher IGF-I protein concentrations around the wound perimeter compared with biopsies from rats treated with vehicle or saline $(p<$ 0.05; Table 3). There were no differences among groups in IGF-I protein concentration in serum, liver, spleen, or kidney (Table 4).

\section{Biological Efficacy}

Thirty-three days after the thermal injury, rats receiving the IGF-I cDNA construct showed a significant increase in proliferation of keratinocytes, mainly basal cells, compared with those receiving vehicle or saline $(p<0.05$; Fig. 3$)$. A higher proliferation of skin cells could be corroborated with accelerated reepithelization. After the eschar was removed, the area of burn wound re-epithelization could be measured. At 28 and 33 days after the thermal injury, rats receiving the IGF-I cDNA construct showed a significant increase in re-epithelization when compared with those receiving vehicle or saline ( $p<0.05$; Fig. 4$)$. These data suggest that the translated protein is biologically effective.

\section{Discussion}

When it was established that genetic information was transferred through DNA and not by genetic proteins or polysaccharides, many new research and therapeutic applications appeared. One of these was gene therapy to modify pathologic conditions at the molecular level. Research areas for gene therapy include oncologic, infectious, neurologic, and cardiovascular diseases (Firedmann, 1997; Lasic, 1998). The use of transient gene therapy after trauma is one of the new approaches to improve clinical outcomes and mortality. The selection of the appropriate vector for gene delivery is a major concern (Felgner, 1997; Firedmann, 1997). In the past, viral vectors have been used for gene therapy due to their specificity for binding and interacting with cells (Felgner, 1997; Firedmann, 1997). Doubts about the safety of the viral vectors have originated from their ability to induce immunologic responses and their potential mutagenic characteristic. Therefore, liposomes have become an attractive non-viral delivery system. Liposomes are vesicular colloidal particles of amphiphilic molecules that contain a hydrophilic polar head and a nonpolar hydrophobic tail. Amphiphiles, such as lecithin, form spherical structures in which the polar heads protect the nonpolar interior against rapid degradation. The nonviral composition, lack of cytotoxicity, increased infectivity, and anti-inflammatory properties have made the use of cholesterol-containing cationic liposomes an attractive approach for dermal gene therapy and for 

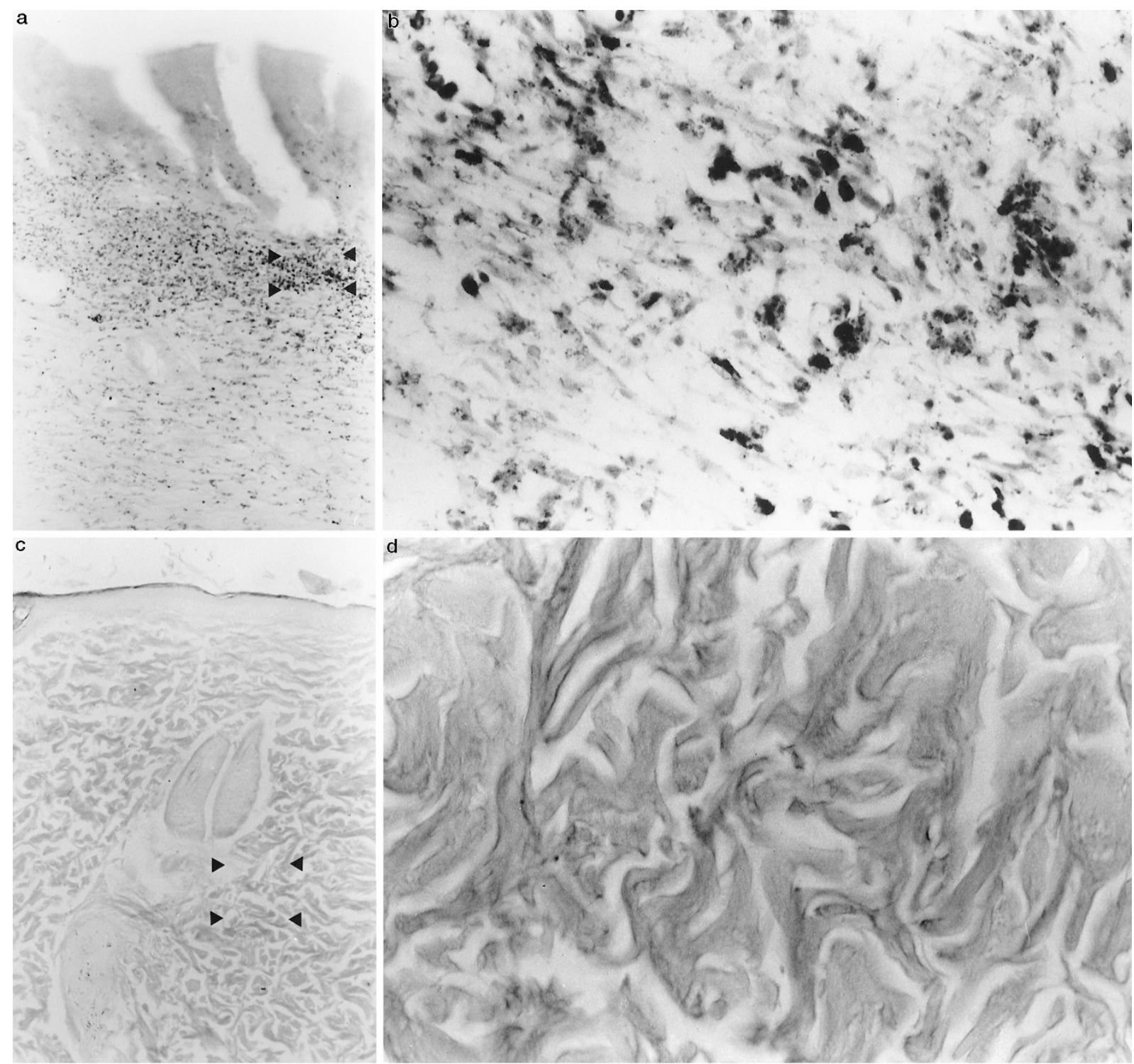

\section{Figure 1.}

Representative photomicrographs of the wound edge taken 33 days after burn and 5 days after the last injection. Sections show histochemical reaction for $\beta$-galactosidase. a, Representative section of skin injected with liposomes containing the IGF-I and Lac Z gene complexes. The reaction product for $\beta$-galactosidase is present within several layers of the skin at the wound edge; original magnification, $\times 80$. b. Enlarged section of a (indicated by arrows); original magnification, $\times 380$. A finely granular blue-green reaction product is present within many myofibroblastic and histiocytic cells in the granulation tissue underlying the burn wound. c, Representative section of dermal tissue at the wound edge of thermally injured rats receiving saline (control). No reaction product could be identified; original magnification, $\times 80$. d, Enlarged section of $c$ (indicated by arrows); original magnification, $\times 380$. Saline-injected (control) dermal tissue underlying uninjured skin near the burn wound showed no reaction product for $\beta$-galactosidase.

ameliorating the burn-induced hypermetabolic response (Filion and Philips, 1997; Jeschke et al, 1999). The mechanisms of gene transfer, biodistribution properties, systemic organ transfection or deposition, cellular uptake mechanisms, and whether the translated protein is biologically effective in the skin has not been studied in detail.

Transfected cells in the injured skin identified after subcutaneous injection of liposomes containing the IGF-I CDNA and the reporter Lac Z construct were myofibroblasts, endothelial cells, and macrophages, including multinucleate giant cells, all of which are known to be proliferative. For gene expression to occur, DNA plasmids enter the cell and its cell nu- cleus. Although there are three possible pathways of cell entry, endocytosis is likely the principal mechanism for transfection (Caplen et al, 1995; Lasic, 1998; Miller et al, 1998; Noguchi et al, 1998). After cellular uptake, the released cDNA is taken up by the nucleus (Felgner et al, 1995). The nuclear membrane represents a barrier to the entry of DNA into the nucleus that is absent during cell division, suggesting that transfection may be more efficient in rapidly dividing cells (Felgner et al, 1995). This is in agreement with our current findings (Felgner et al, 1995). Ribosomes transcribe the nuclear cDNA into mRNA, which is then transported to the rough endoplasmic reticulum where it is translated into protein. Our observation that 
Table 1. $\beta$-galactosidase Expression in the Skin

$\beta$-galactosidase (counts/second/ml extract) Group

\begin{tabular}{lccc} 
& \multicolumn{3}{c}{ Group } \\
\cline { 2 - 4 } $\begin{array}{c}\text { Site of } \\
\text { skin biopsy }\end{array}$ & $\begin{array}{c}\text { Saline } \\
(\mathrm{n}=10)\end{array}$ & $\begin{array}{c}\text { Vehicle } \\
(\mathrm{n}=10)\end{array}$ & $\begin{array}{c}\text { IGF-I cDNA } \\
(\mathrm{n}=10)\end{array}$ \\
\hline Proximal & $2743 \pm 515^{\star}$ & $5796 \pm 591$ & $6489 \pm 776$ \\
Distal & $2858 \pm 556^{\star}$ & $5267 \pm 325$ & $6555 \pm 811$ \\
\hline
\end{tabular}

Data presented as means \pm SEM

* Significant difference $v s$ liposomes and IGF-I cDNA $(p<0.05)$.

mRNA for IGF-I was only detected in the skin of transfected rats is consistent with increases in skin IGF-I protein concentrations. Our data indicate that cDNA encoding for $\beta$-galactosidase and IGF-I was transcribed and translated into $\beta$-galactosidase and IGF-I protein in the skin.

To evaluate whether the transferred IGF-I cDNA was biologically active, we measured skin cell proliferation (Martin, 1997). We have shown that the translated IGF-I gene is biologically active in enhancing dermal cell proliferation, suggesting that myofibroblasts, endothelial cells, and macrophages, including multinucleate giant cells, which were identified to be transfected, produce biologically active IGF-I, and exert autocrine, paracrine, or endocrine effect.

It has been suggested that the skin may be used as a delivery system for gene products because foreign gene products synthesized in the epidermis have been shown to reach the systemic circulation (Alexander and Akhurst, 1995). In the present study, no transfection or increase in $\beta$-galactosidase or IGF-I expression

Table 2. $\beta$-galactosidase Expression in Blood, Liver, Kidney, and Spleen

\begin{tabular}{lccc}
\hline \multicolumn{4}{c}{$\beta$-Galactosidase (counts/second/ml extract) } \\
Group \\
\cline { 2 - 4 } & Saline & Vehicle & IGF-I cDNA \\
& $(\mathrm{n}=10)$ & $(\mathrm{n}=10)$ & $(\mathrm{n}=10)$ \\
\hline Blood & $349 \pm 37$ & $235 \pm 48$ & $244 \pm 116$ \\
Liver & $1757 \pm 139$ & $1881 \pm 956$ & $1620 \pm 886$ \\
Kidney & $964 \pm 90$ & $896 \pm 100$ & $916 \pm 98$ \\
Spleen & $1154 \pm 217$ & $1460 \pm 348$ & $886 \pm 379$ \\
\hline
\end{tabular}

Data presented as means \pm SEM.

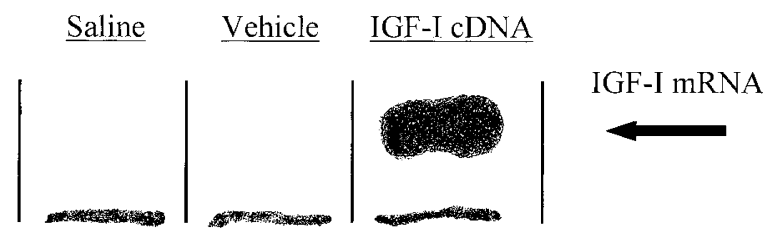

Figure 2.

Representative, computerized cartoon of the IGF-I mRNA. The absorbance was measured and plotted as a cartoon according to the absorbance. No IGF-I mRNA could be detected in skin biopsies from rats transfected with vehicles or saline. There was a significant amount of IGF-I mRNA in skin biopsies from rats transfected with IGF-I CDNA.
Table 3. IGF-I Protein Concentration in Skin

\begin{tabular}{llll}
\hline & \multicolumn{3}{c}{ IGF-I protein $(\mathrm{ng} / \mathrm{ml})$} \\
Group \\
\cline { 2 - 4 } $\begin{array}{c}\text { Site of skin } \\
\text { biopsy }\end{array}$ & $\begin{array}{c}\text { Saline } \\
(\mathrm{n}=10)\end{array}$ & $\begin{array}{c}\text { Vehicle } \\
(\mathrm{n}=10)\end{array}$ & $\begin{array}{c}\text { IGF-I cDNA } \\
(\mathrm{n}=10)\end{array}$ \\
\hline Proximal & $96 \pm 5$ & $109 \pm 8$ & $176 \pm 13^{*}$ \\
Distal & $96 \pm 11$ & $113 \pm 11$ & $171 \pm 13^{*}$ \\
\hline \multicolumn{2}{c}{$\begin{array}{l}\text { Data presented as means } \pm \text { SEM. } \\
\text { * Significant difference vs liposomes and saline, } \mathrm{p}<0.05 .\end{array}$}
\end{tabular}

in blood, liver, spleen, or kidney could be demonstrated. We therefore suggest that after subcutaneous injections of liposomal gene constructs, no systemic transfection occurs. However, this suggestion is in contrast to previously published studies (Li and Hoffmann, 1995a; Palmer et al, 1991). A possible explanation for not finding systemic transfection is the lack of sensitivity of the tests used in this study. The chemiluminescent and radioactive immunoassays are able to detect small amounts of the proteins, but their sensitivity may be too low to detect the differences in our samples.

In the present study we have shown that the subcutaneous administration of liposome-encapsulated Lac Z and IGF-I cDNA constructs successfully transfected skin cells and that the cDNA was transcribed into mRNA and translated into protein. The process of transfection, transcription, and translation was restricted to the skin and the transferred cDNA was biologically active as shown by an increase in skin cell proliferation and acceleration of re-epithelization. From these findings we conclude that cholesterolcontaining cationic liposomes encapsulating an expression plasmid vector for cDNA are effective in delivering biologically active proteins to the skin, and that they remain in the skin without any systemic transfection, thus allowing specific targeting. This finding is of importance for IGF-I therapy after trauma.

IGF-I has been shown to improve metabolism, gut mucosal function, and protein losses after a thermal injury (Huang et al, 1993; Meyer et al, 1996; Strock et al, 1990). It mediates the actions of growth hormone in the hypermetabolic state by attenuating lean body mass loss, and improving the compromised immune

Table 4. IGF-I Protein Concentration in Blood, Liver, Kidney, and Spleen

\begin{tabular}{lccc}
\hline \multicolumn{4}{c}{ IGF-I protein $(\mathrm{ng} / \mathrm{ml})$} \\
& \multicolumn{3}{c}{ Group } \\
\cline { 2 - 4 } & $\begin{array}{c}\text { Saline } \\
(\mathrm{n}=10)\end{array}$ & $\begin{array}{c}\text { Vehicle } \\
(\mathrm{n}=10)\end{array}$ & $\begin{array}{c}\text { IGF-I cDNA } \\
(\mathrm{n}=10)\end{array}$ \\
\hline Blood & $139 \pm 2$ & $132 \pm 5$ & $135 \pm 5$ \\
Liver & $177 \pm 3$ & $181 \pm 6$ & $172 \pm 6$ \\
Kidney & $188 \pm 4$ & $186 \pm 12$ & $188 \pm 8$ \\
Spleen & $160 \pm 3$ & $150 \pm 7$ & $156 \pm 6$ \\
\hline
\end{tabular}

Data presented as means \pm SEM. 


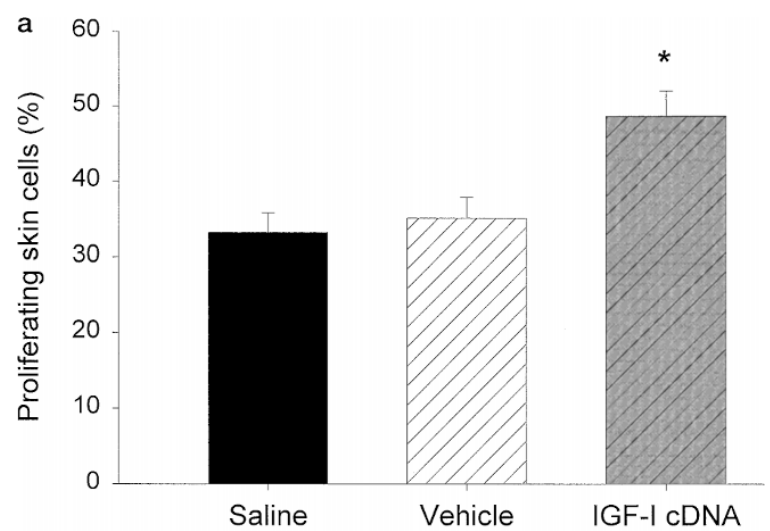

b

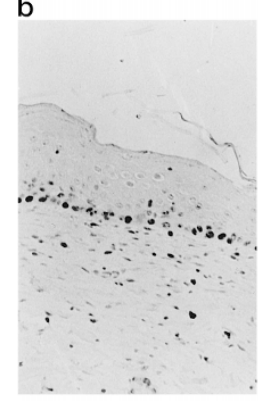

Saline

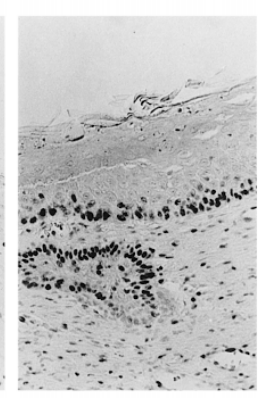

Vehicle

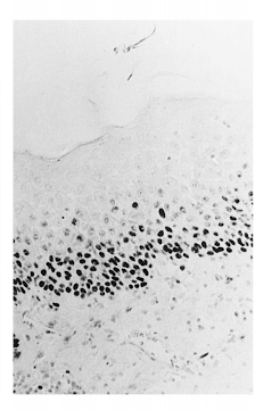

IGF-ICDNA
Figure 3

Skin cell proliferation determined by proliferating cell nuclear antigen (PCNA). a, Quantification of proliferating skin cells in thermally injured rats receiving the IGF-I cDNA construct, vehicle, or saline. * , Significant difference between rats receiving the IGF-I gene complex versus vehicle or saline; $p<0.05$. Data are presented as means \pm SEM. $b$, Representative histologic section of dermal tissue at the wound edge in rats receiving saline, vehicle, or the IGF-I cDNA construct. Dark staining (red-brown) was considered positive for proliferating skin cells. Mainly basal cells were found to be positive, thus undergoing proliferation; original magnification, $\times 200$.

system and acute phase response (Clemmons, 1994; Guler et al, 1988; Meyer et al, 1996). Treatment with IGF-I has been shown to accelerate wound healing by stimulating collagen synthesis and the mitogenicity of fibroblasts and keratinocytes (Guler et al, 1988; Martin, 1997). Several adverse side effects, such as hypoglycemia, mental status changes, edema, fatigue, and headache, however, have limited the use of IGF-I in the treatment of burns (Bondy et al, 1994; Jabri et al, 1994). These adverse side effects are most likely due to supraphysiologic doses of free IGF-I (Bondy et al, 1994; Jabri et al, 1994). In the present study we demonstrated that non-viral liposomal gene therapy increases IGF-I concentrations locally without any of the known systemic adverse side effects that have been associated with therapeutic doses. We therefore suggest that cholesterol-containing cationic lipoplexes are effective and safe as a vector and the local transient transfection of IGF-I genes make this approach attractive for the therapeutic clinical use.

\section{Materials and Methods}

Thirty adult male Sprague-Dawley rats (350 to $375 \mathrm{~g}$ ) were placed in wire-bottom cages housed in a

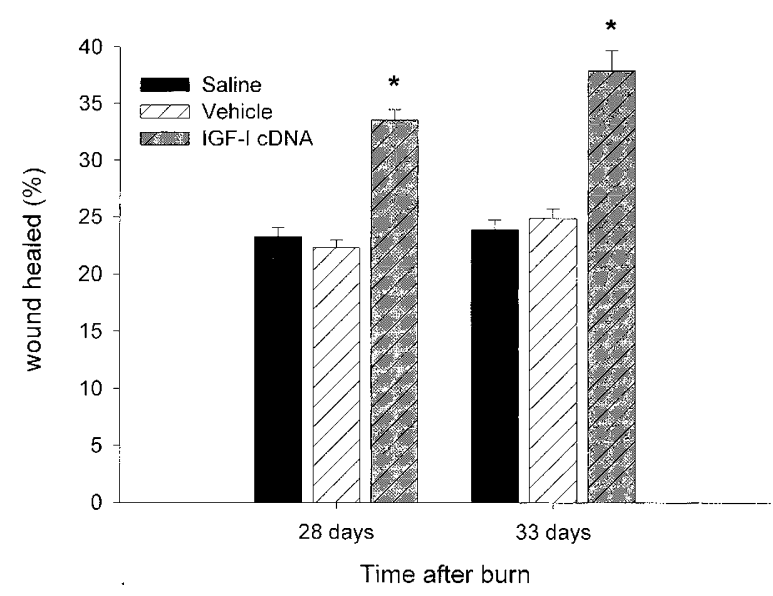

Figure 4.

Area of wound re-epithelization was measured by planimetry. Rats receiving encapsulated IGF-I cDNA constructs had the highest percentage of reepithelization throughout the study period compared with the vehicle or saline groups. *, IGF-I cDNA versus vehicle and saline $(p<0.05)$. Data are presented as means \pm SEM.

temperature-controlled room with a 12-hour light-dark cycle. Rats were acclimatized to their environment for 7 days before the blinded study. All received similar amounts of a liquid diet of Sustacal (Mead Johnson Nutritionals, Evansville, Indiana) and water ad libitum throughout the study. Each rat received a $60 \%$ total body surface area full-thickness scald burn under general anesthesia (Pentobarbital $50 \mathrm{mg} / \mathrm{kg}$ body weight) and analgesia (Buprenorphin $1 \mathrm{mg} / \mathrm{kg}$ body weight), after a modified procedure as previously described (Herndon et al, 1978). Rats were anesthetized, shaved, placed in a mole, and received a $60 \%$ total body surface area scald burn $\left(99^{\circ} \mathrm{C}\right.$ hot water; water contact 10 seconds to the back and $1.5 \mathrm{sec}-$ onds to the belly). After the thermal injury rats were immediately resuscitated by intraperitoneal injection of Ringer's lactate (50 ml/kg body weight). Thermally injured rats were then randomly divided into 3 groups to receive:

1. Weekly subcutaneous injections of saline $(200 \mu \mathrm{l}$ normal saline); controls, $n=10$.

2. Weekly subcutaneous injections of liposomes (10 $\mu \mathrm{l}$ liposomes in $180 \mu \mathrm{l}$ saline) containing $0.2 \mu \mathrm{g}$ of the reporter gene for $\beta$-galactosidase Lac Z cDNA construct; vehicle, $n=10$.

3. Weekly subcutaneous injection of liposomes (10 $\mu$ l liposomes in $180 \mu$ l saline) containing $2.2 \mu \mathrm{g}$ of an IGF-I cDNA construct and $0.2 \mu \mathrm{g}$ of the reporter gene $\beta$-galactosidase Lac Z cDNA construct; $n=$ 10.

The rat IGF-I cDNA construct consisted of a CMVdriven IGF-I cDNA plasmid prepared at the University of Texas Medical Branch, Sealy Center for Molecular Science Recombinant DNA Core Facility. (The IGF-I cDNA was kindly supplied by Dr. P. Rotwein, National Institutes of Health.) The liposomes were formulated from 1:1 (M/M) DMRIE (1, 2-dimyristyloxypropyl-3dimethyl-hydroxyl ethyl ammonium bromide) and cholesterol suspended in membrane-filtered water (Life 
Technologies, Rockville, Maryland). This reagent interacts spontaneously with IGF-I cDNA to form the lipid cDNA complex.

Immediately after the thermal injury, each rat received $0.2 \mathrm{ml}$ of the lipoplexes subcutaneously injected at two sites opposite from each other. This treatment was repeated each week for 4 weeks. Mixtures were freshly prepared before injections. Animals were humanely killed by decapitation 5 days after the last injection. Blood was collected into serum and plasma separators, spun at $1000 \mathrm{~g}$ for 15 minutes, and the supernatant and pellet were separated and stored at $-73^{\circ} \mathrm{C}$. Samples of liver, kidney, spleen, and skin from the back were harvested, snap-frozen in liquid nitrogen, and stored at $-73^{\circ} \mathrm{C}$ for analysis.

\section{Histologic Determination of $\beta$-galactosidase}

Transfection was determined in skin samples taken 33 days after burn and 5 days after the last injection by measuring the presence of $\beta$-galactosidase. The presence of the $\beta$-galactosidase protein was detected by histochemical staining with Bluo-Gal (halogenated indolyl- $\beta$-D-galactoside; LIFE Technologies, Gaithersburg, Maryland) for $\beta$-galactosidase in the skin. Linear skin biopsies were taken as follows: two skin biopsies were taken from skin close to the injection site (defined as proximal) and one was taken from the furthest point from the injection site (defined as distal). The biopsies were approximately $4-\mathrm{mm}$ wide and extended from the center of the burn wound well into surrounding normal skin. Skin specimens were fixed overnight at $4^{\circ} \mathrm{C}$ in fixative consisting of $4 \%$ paraformaldehyde in a HEPES-buffered Hanks solution at $\mathrm{pH}$ 7.6. After washing in buffer and phosphate-buffered saline (PBS), the specimens were incubated overnight at $37^{\circ} \mathrm{C}$ in a $0.1 \%$ solution of Bluo-Gal substrate, buffered to $\mathrm{pH}$ 7.6. After washing, tissues were embedded in paraffin, and histologic sections were made and stained with hematoxylin and eosin or with eosin alone.

\section{Chemiluminescent Determination of $\beta$-galactosidase}

The presence of $\beta$-galactosidase protein was detected by chemiluminescent reporter gene assays (Galacto-light plus; Tropix Inc., Bedford, Massachusetts) in skin, blood cells, liver, kidney, and spleen 33 days postburn (O'Connor and Culp, 1994). Samples were prepared as follows: samples (weighing approximately $100 \mathrm{mg}$ ) were homogenized in Lysis buffer (40 $\mathrm{mm}$ Tris $\mathrm{pH} 7.5,1 \mathrm{~mm}$ EDTA, $150 \mathrm{~mm} \mathrm{NaCl}$ ) in a ratio $1: 2$ (100 mg skin in $200 \mu$ l buffer) for approximately 30 seconds. Samples were centrifuged $(12,000 \times g)$ for 3 minutes. The supernatant was removed, the volume was measured, and the sample was stored on ice. The residual pellet was rinsed with $200 \mu$ l lysis buffer and micro centrifuged. The assay used 96-well plates, as suggested by the manufacturer's instructions.

\section{IGF-I m RNA in the Skin}

Total RNA was extracted from skin cells from control or cotransfected with IGF-I cDNA and $\beta$-gal cDNA PC 12 monolayers by the acid guanidinium thiocyanatephenol chloroform method and RNA abundance measured by spectrophotometry. RNA $(20 \mu \mathrm{g})$ was fractionated on a 1.2\% agarose-formaldehyde gel and transferred to nylon-reinforced nitrocellulose membrane (S \& S, Munich, Germany) overnight via TurboBlotter downward transfer systems using $20 \times$ SSC. Blots were rinsed in $5 \times$ SSC to remove bits of gel or particles from the membrane. To immobilize the nucleic acid on the membrane, blots were incubated at $45^{\circ} \mathrm{C}$ for 4 hours and then exposed to ultraviolet light (254 to $312 \mathrm{~nm}$ ) for approximately 3 minutes. Membranes were blocked and pre-hybridized in Quik Hyb hybridization solution (Stratagene, La Jolla, California) plus denatured salmon sperm DNA at $45^{\circ} \mathrm{C}$ overnight. The IGF-I cDNA probes were cut twice from the IGF-I cDNA plasmid, at the $\mathrm{EcoRI}$ and $K p n l$ restriction site. Digesting times were 4 hours. The probes were then run on $1.5 \%$ agarose gels in $0.5 \times$ TBE buffer. The size of the IGF-I cDNA probe was $816 \mathrm{bp}$. We used DNA molecular weight marker VII (Boehringer, Mannheim, Germany) as a marker to cut the IGF-I cDNA probe in the gel and Qiaex II agarose gel extraction kits (Qiagen, Camarillo, California) to extract and purify the IGF-I cDNA probe. The IGF-I cDNA probes were labeled by random priming (Rediprime; Amersham,

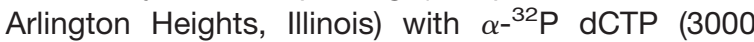
$\mathrm{Ci} / \mathrm{mmol}$; ICN Biomedicals, Costa Mesa, California; 1 $\mathrm{mCi}=37 \mathrm{GBq})$. RNA samples were hybridized overnight at $42^{\circ} \mathrm{C}$ with 1 to $2 \times 10^{6} \mathrm{cpm} / \mathrm{ml}$ of labeled probe. Membrane was washed four times at $42^{\circ} \mathrm{C}$ in $3 \times$ SSC, $0.1 \%$ SDS three times for 15 minutes and then in $0.1 \%$ SSC, $0.1 \%$ SDS for 30 minutes. Blots were exposed to a Phosphor-Imager screen.

\section{IGF-I Protein}

IGF-I protein concentrations were measured by rat radioimmunoassay $(R I A)$ in serum, liver, kidney, spleen, and skin. Skin IGF-I protein concentrations were measured in skin biopsies taken 33 days after burn, defined as proximal to injection site and distal to injection site. Proteins were extracted by pulverizing approximately $40 \mathrm{mg}$ of tissue under liquid nitrogen, adding an extraction buffer (PBS ${ }^{-}, 0.25 \mathrm{ml}$ PMSF, 50 mg leupeptin, $100 \mathrm{mg}$ aprotinin, and $50 \mathrm{mg}$ antipain) in a volume 1:7 (7 ml buffer/gram tissue) and homogenizing the mixture. To allow proteins to recover, samples were frozen overnight at $-80^{\circ} \mathrm{C}$. After thawing, $50 \mu \mathrm{l}$ of the homogenate was added to $150 \mu \mathrm{l}$ of extraction solution and centrifuged at 13,500 rpm for 5 minutes. Then, $100 \mu$ l of supernatant was added to $400 \mu$ l of neutralization solution, and the rat IGF-I RIA was performed as described in the kit guidelines (Diagnostic System Laboratories, Webster, Texas). 


\section{Methods for Determining Biological Efficacy}

Biological efficacy of the delivery system was defined by measuring dermal cell proliferation. Skin biopsies were taken from the wound edge at 33 days after burn ( 5 days after the last injection) and dermal cell proliferation was determined by proliferating cell nuclear antigen (PCNA) immunohistochemical staining. PCNA stains the proliferating cells (G1-M cycle). All skin cells in the pannus and along the basal layer were counted. Proliferation was then determined by positive stained skin cells per hundred counted skin cells. An observer blinded to the treatment groups was recruited to count the cells.

Wound healing was determined as follows: The wound eschar was left intact for the first 28 days and then removed by gentle traction, caution being taken not to disturb or destroy the healing edge along the periphery. After removing the eschar, the animals were placed on a standard surface and the wound area was traced onto acetate sheets along the well-demarcated re-epithelized and nonburned interface and the leading edge of the neo-epithelium. The areas of these tracings were calculated by computerized planimetry (Sigma Scan and Sigma Plot software, San Rafael, California). Values are expressed as percentage reepithelization from the original burn wound.

\section{Ethics and Statistics}

These studies were reviewed and approved by the Animal Care and Use Committee of the University of Texas Medical Branch, Galveston, Texas, assuring that all animal received humane care according to the criteria outlined in the National Institutes of Health Guide for the Care and Use of Laboratory Animals. Statistical comparisons were made by ANOVA and Student's $t$ test with the Bonferroni correction. Data are expressed as means \pm standard error of the mean (SEM). Significance was accepted at $p<0.05$.

\section{Acknowledgements}

This study was supported by the Clayton Foundation for Research and the Shriners Hospital for Children. The authors thank Anne S Burke and Shahnaz Quadeer for their technical help.

\section{References}

Alexander MY and Akhurst RJ (1995). Liposome-mediated gene transfer and expression via the skin. Hum Mol Gen 4:2279-2285.

Bondy CA, Underwood LE, Clemmons DR, and Guler HP (1994). Clinical uses of insulin-like growth factor-I. Ann Int Med 120:593-601.

Caplen NJ, Alton EWFW, and Middleton PG (1995). Nat. Med. 1:39-46.

Clemmons DR (1994). Insulin-like growth factor-1 as an anabolic agent in catabolic states. Ann Intern Med 120:596597.
Felgner PL (1997). Nonviral strategies for gene therapy. Sci Amer 6:102-106.

Felgner PL, Tsai YL, and Sukhu L (1995). Improved cationic lipid formulations for in vivo gene therapy. Ann NY Acad Sci 772:126-139.

Felgner PL (1996). Improvements in cationic liposomes for in vivo gene transfer. Hum Gen Ther 7:1791-1793.

Filion MC and Philips NC (1997). Anti-inflammatory activity of cationic liposomes. Br J Pharmacol 122:551-557.

Firedmann T (1997). Overcoming the obstacles to gene therapy. Sci Amer 6:96-101.

Guler HP, Zapf J, Scheiwiller E, and Froesch ER (1988). Recombinant human insulin-like growth factor-1 stimulates growth and has distinct effects on organ size in hypophysectomized rats. Proc Natl Acad Sci USA 85:4889-4893.

Herndon DN, Barrow RE, Kunkel KR, and Rutan RL (1990). Effects of recombinant human growth hormone on donor-site healing in severely burned children. Ann Surg 212:424-431.

Herndon DN, Wilmore DW, Mason AD Jr, and Pruitt BA Jr (1978). Development and analysis of a small animal model stimulating the human postburn hypermetabolic response. J Surg Res 25:394-403.

Huang KF, Chung DH, and Herndon DN (1993). Insulin-like growth factor-1 (IGF-I) reduces gut atrophy and bacterial translocation after severe burn injury. Arch Surg 128:47-54.

Jabri N, Schalch DS, Schwartz SL, and Fischer JS (1994). Adverse effects of recombinant human insulin-like growth factor-I in obese insulin-resistant type II diabetic patients. Diabetes 43:369-374.

Jeschke MG, Barrow RE, Perez-Polo JR, and Herndon DN (1999). Cholesterol-containing cationic liposomes as a delivery system for gene therapy attenuates pro-inflammatory cytokines. Arch Surg 134:1098-1102.

Lasic DD (1998). Liposomes in gene delivery. In: Lasic DD, editor. Liposomes in gene delivery. New York: CRC Press, 189-197.

Lee ER, Marshall J, and Siegel CS (1996). Detailed analysis of structures and formulations of cationic lipids for efficient gene transfer to the lung. Hum Gene Ther 7:1701-1717.

Li L and Hoffman RM (1995a). The feasibility of targeted selective gene therapy of the hair follicle. Nature Med 1:705706.

Li L and Hoffman RM (1995b). Model of selective gene therapy of hair growth: Liposome targeting of the active lac-Z gene to hair follicles histocultured skin. In Vitro Cell Dev Biol 31A: 11-13.

Mahato RI, Anwer K, Tagliaferri F, Meaney C, Leonard P, Wadhwa MS, Logan M, French M, and Rolland A (1998). Biodistribution and gene/expression of lipid/plasmid complexes after systemic administration. Hum Gene Ther 9:2083-2099.

Martin P (1997). Wound healing-aiming for perfect skin regeneration. Science 276:75-81.

Meyer NA, Barrow RE, and Herndon DN (1996). Combined insulin-like growth factor-1 and growth hormone improves weight loss and wound healing in burned rats. J Trauma 31:1008-1012. 
Miller CR, Bondurant B, McLean SD, and McGovern KA (1998). Liposome-cell interactions in-vitro: Effect of liposome surface charge on the binding and endocytosis of conventional and sterically stabilized liposomes. Biochemistry 37 : 12875-12883.

Noguchi A, Furuno T, Kawaura C, and Nakanishi M (1998). Membrane fusion plays an important role in gene transfection mediated by cationic liposomes. FEBS Lett 433:169-173.

O'Connor KL and Culp LA (1994). Quantification of two histochemical markers in the same extract using chemiluminescent substrates. Biotechniques 17:502-509.
Palmer TD, Rosman GJ, Osborne WRA, and Miller AD (1991). Genetically modified skin fibroblasts persist long after transplantation but gradually inactivate produced genes. Proc Natl Acad Sci USA 88:1330-1334.

Strock LL, Singh H, and Abdullah A (1990). The effect of insulin-like growth factor-1 on postburn hypermetabolism. Surgery 108:161-164.

Wheeler CJ, Felgner PL, and Tsai YT (1996). A novel cationic lipid greatly enhances plasmid DNA delivery and expression in mouse lung. Proc Natl Acad Sci 93:11454-11459. 